\title{
Silicon purification in vacuum induction furnace
}

Purificação de silício em forno de indução a vácuo

André Alexandrino Lotto ${ }^{1}$; João Batista Ferreira Neto ${ }^{1}$; Marcelo B. Mourão²

\section{ABSTRACT}

In this paper the removal of impurities from metallurgical grade silicon by vacuum melting in an induction furnace was studied, in order to produce solar grade silicon, which is raw material of the photovoltaic cells to convert solar energy into electricity. The work was focused on the removal of phosphorus, which is one of the most difficult impurities to remove from silicon. Phosphorus concentration dropped from $119 \mathrm{ppm}$ to 8 ppm of phosphorus in 3 hours at $1650^{\circ} \mathrm{C}$ under pressure of $0.2 \mathrm{~Pa}$. It was concluded that this method is technically feasible for purification of metallurgical grade silicon. The kinectic rates constants were obtained for phosphorus $\left(k_{\mathrm{P}}=5 \cdot 10^{-6} \mathrm{~m} / \mathrm{s}\right)$, aluminum $\left(\mathrm{k}_{\mathrm{Al}}=2 \cdot 10^{-6}\right.$ $\mathrm{m} / \mathrm{s}$ ) and calcium $\left(\mathrm{k}_{\mathrm{Ca}}=1 \cdot 10^{-5} \mathrm{~m} / \mathrm{s}\right)$. Silicon losses by vaporization during the test averaged around $13 \%$.

Keyword: Purification; Silicon; Vacuum.

\section{RESUMO}

Neste trabalho foi estudada a remoção de impurezas de silício grau metalúrgico por fusão em forno de indução a vácuo, com o objetivo de produzir silício grau solar, que é matéria-prima de células fotovoltaicas para conversão de energia solar em elétrica. O trabalho foi focado na remoção de fósforo, que é uma das impurezas mais difíceis de serem removidas do silício. O teor de fósforo foi reduzido de 119 ppm para 8 ppm em 3 horas a $1650^{\circ} \mathrm{C}$ sob pressão de $0.2 \mathrm{~Pa}$, obtida por um conjunto de bombas mecânica, tipo "roots" e difusora. Concluiu-se que este método é técnicamente viável para purificar silício grau metalúrgico. Foram obtidas constantes cinéticas de remoção de fósforo $\left(k_{\mathrm{P}}=5 \cdot 10^{-6} \mathrm{~m} / \mathrm{s}\right)$, alumínio $\left(\mathrm{k}_{\mathrm{Al}}=2 \cdot 10^{-6} \mathrm{~m} / \mathrm{s}\right)$ e cálcio $\left(\mathrm{k}_{\mathrm{Ca}}=1 \cdot 10^{-5} \mathrm{~m} / \mathrm{s}\right)$. As perdas médias de silício por vaporização durante os testes foram de $13 \%$.

Palavras-chave: Purificação; Silício; Vácuo.

${ }^{1}$ Instituto de Pesquisas Tecnológicas do Estado de São Paulo (IPT) - São Paulo (SP), Brasil.

¿Universidade de São Paulo (USP) - São Paulo (SP), Brasil.

Endereço para correspondência: André Alexandrino Lotto - Avenida Professor Almeida Prado, 532, Butantã - CEP: 05508-901 - São Paulo (SP), Brazil. E-mail: andrelotto@ipt.br

Recebido em: 22/10/2013 Aprovado em: 19/11/2014 


\section{INTRODUCTION}

Silicon used in solar cells was made with scraps of electronic grade silicon, EG-Si (99.9999999 \% Si), which is purer (and expensive) than required for the conversion of solar energy. With the increasing demand for solar cells, specific processes are being developed to produce solar grade silicon (SoG-Si), either by adapting the production route of EG-Si or by alternative routes such as pyrometallurgical purification of metallurgical grade silicon, MG-Si ( $98 \%$ to $99.5 \%$ purity). This work fits into the alternative route metallurgical purification and aims to explore one of the techniques used to purify metals, the use of vacuum melting, applying it to the MG-Si. This technique has the potential to remove phosphorus, one of the impurities in the MG-Si that negatively affects the properties of the solar cells.

The vacuum melting is traditionally employed in processes such as melting high reactivity alloys and controlled composition materials. This refining principle is to favor the reaction of evaporation of the more volatile elements than the solvent, shifting the chemical equilibrium towards the formation of gaseous phases ${ }^{(1)}$.

\section{EXPERIMENTAL PROCEDURE}

$0.514 \mathrm{~kg}$ of metallurgical grade silicon were melted under argon atmosphere in a high density graphite crucible $\left( \pm 1800 \mathrm{~kg} / \mathrm{m}^{3}\right.$ and Øint $=0.098 \mathrm{~m}$ ). Upon completion of melting, the first sample was collected. Sampling was done in high purity graphite samplers. After the first sampling, the evacuation of the furnace began slowly to minimize short splashes of liquid due to the presence of oxide in the material. The chamber pressure during the test was between 0.1 and $0.2 \mathrm{~Pa}$ and the temperature at $1923 \mathrm{~K}\left(1650^{\circ} \mathrm{C}\right)$.

Beyond the first, more ten samples were collected over $10.8 \mathrm{ks}$ ( 3 hours). The samples were analyzed by inductively coupled plasma atomic emission spectroscopy (ICP-AES).

The material used in the experiment was metallurgical grade silicon. The complete chemical composition of this silicon is shown in Table 1.

Table 1: Chemical composition of the MG-Si used in the experiment.

\begin{tabular}{cc}
\hline Element & Content (pmm) \\
\hline $\mathrm{B}$ & $10 \pm 2$ \\
$\mathrm{Mn}$ & $237 \pm 50$ \\
$\mathrm{Ca}$ & $389 \pm 71$ \\
$\mathrm{P}$ & $119 \pm 4$ \\
$\mathrm{Fe}$ & $7867 \pm 67$ \\
$\mathrm{Cr}$ & $25 \pm 1$ \\
$\mathrm{Ni}$ & $70 \pm 4$ \\
$\mathrm{Ti}$ & $145 \pm 7$ \\
$\mathrm{Mg}$ & $12 \pm 2$ \\
$\mathrm{Na}$ & $206 \pm 57$ \\
$\mathrm{Zr}$ & $332 \pm 18$ \\
$\mathrm{Zn}$ & $11 \pm 1$ \\
$\mathrm{~V}$ & $14 \pm 2$ \\
$\mathrm{Cu}$ & $22 \pm 1$ \\
$\mathrm{Al}$ & $31 \pm 3$ \\
$\mathrm{Ba}$ & $12 \pm 2$ \\
$\mathrm{Co}$ & $30 \pm 1$ \\
\hline
\end{tabular}

A vacuum induction furnace of $30 \mathrm{kVA}$ manufactured by Daido Steel Company was used. It has a rotary vane mechanical pump, a rotary pump "Roots" type and a diffuser pump, which together allow reaching pressures of about $0.02 \mathrm{~Pa}$. The pressure measurement was made using sensors "Pirani" and cold cathode. The temperature measurement was made by two color optical pyrometer. The frequency of the coil was $7 \mathrm{kHz}$. Furnace chamber walls are water cooled and made of stainless steel. Figure 1 shows this furnace.

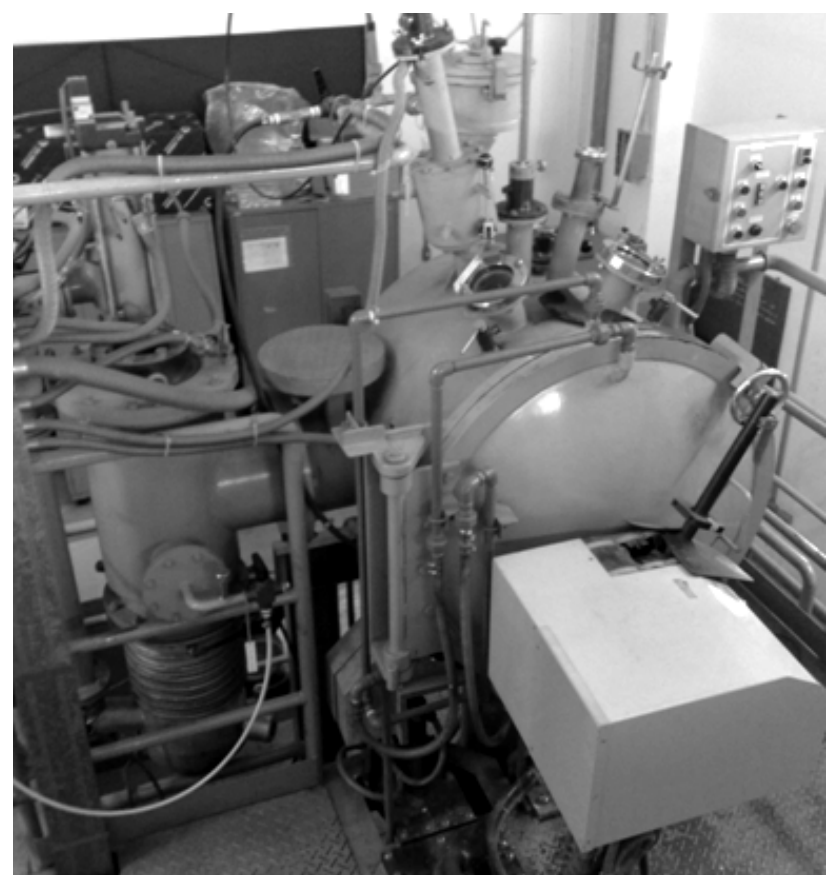

Figure 1: Vacuum induction furnace used in this work.

\section{RESULTS AND DISCUSSION}

Some elements had their impurity levels reduced after the experiment. This is the case of the elements $\mathrm{Mn}, \mathrm{Ca}, \mathrm{P}, \mathrm{Na}, \mathrm{Al}$ and $\mathrm{Mg}$. Figure 2 shows the variation of the compositions of $\mathrm{Mn}, \mathrm{Ca}, \mathrm{P}$ and $\mathrm{Na}$ with time. Phosphorus was reduced from $119 \mathrm{ppm}$ to $8 \mathrm{ppm}$ in three hours.

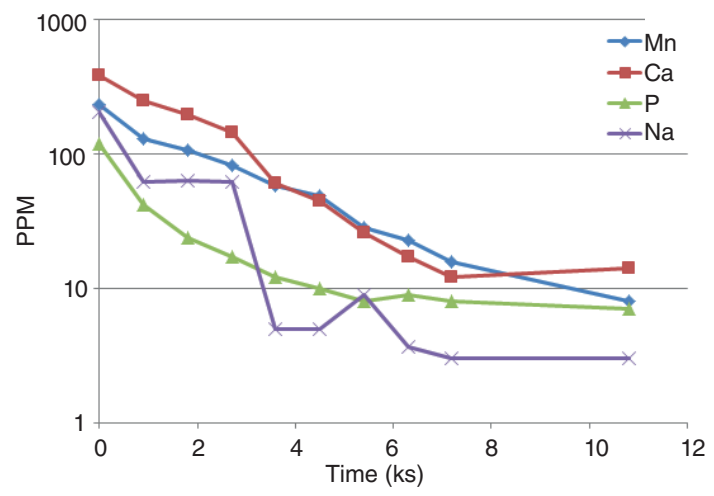

Figure 2: Composition variation with time for $\mathrm{Mn}, \mathrm{Ca}, \mathrm{P}$ and $\mathrm{Na}$ in the bulk silicon. 
For other elements the removal was mild, or there was not removal. This is the case of the elements $\mathrm{Cu}, \mathrm{Zn}, \mathrm{Ti}, \mathrm{Zr}, \mathrm{Ba}, \mathrm{Co}, \mathrm{Fe}$, $\mathrm{B}, \mathrm{Ni}$ and $\mathrm{V}$, while the element $\mathrm{Cr}$ showed a small increase in concentration. This is due to the effect of the concentration of these elements in the liquid with the evaporation of silicon. Figures 3, 4 and 5 show the variation curves of composition versus time for the elements $\mathrm{Cu}, \mathrm{Al}, \mathrm{Zn}$ and $\mathrm{Mg}$; $\mathrm{Ti}, \mathrm{Zr}, \mathrm{Ba}, \mathrm{Fe}$ and $\mathrm{Co}$; and $\mathrm{B}, \mathrm{Cr}, \mathrm{Ni}$ and $\mathrm{V}$, respectively.

The removal of phosphorus curve was compared with data presented at Lotto et $\mathrm{al}^{(2)}$. In this case, silicon with low initial

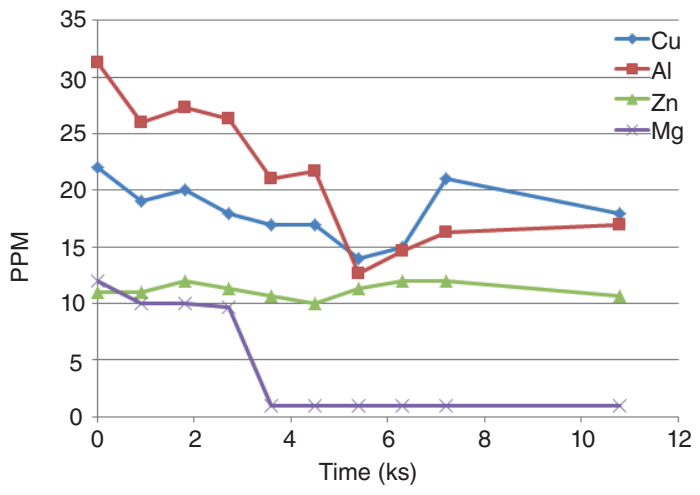

Figure 3: Time dependent variation of composition for the elements $\mathrm{Cu}, \mathrm{Al}, \mathrm{Zn}$ and $\mathrm{Mg}$ in the bulk silicon.

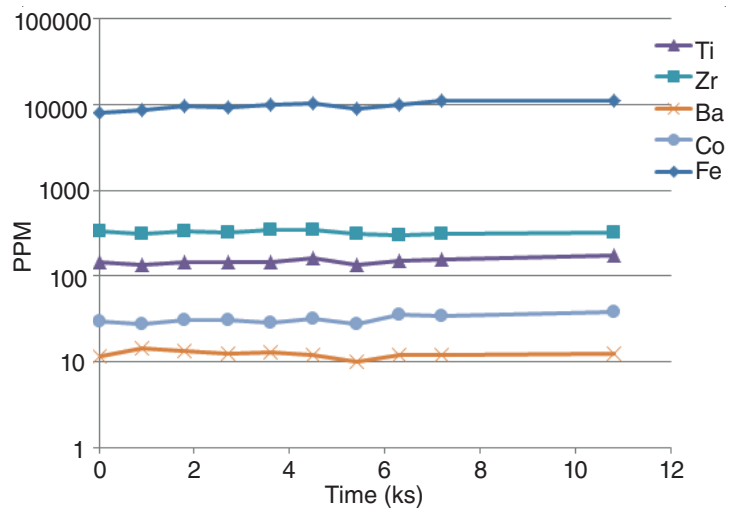

Figure 4: Time dependent variation of composition for the elements $\mathrm{Ti}, \mathrm{Zr}, \mathrm{Ba}, \mathrm{Co}$ and $\mathrm{Fe}$ in the bulk silicon.

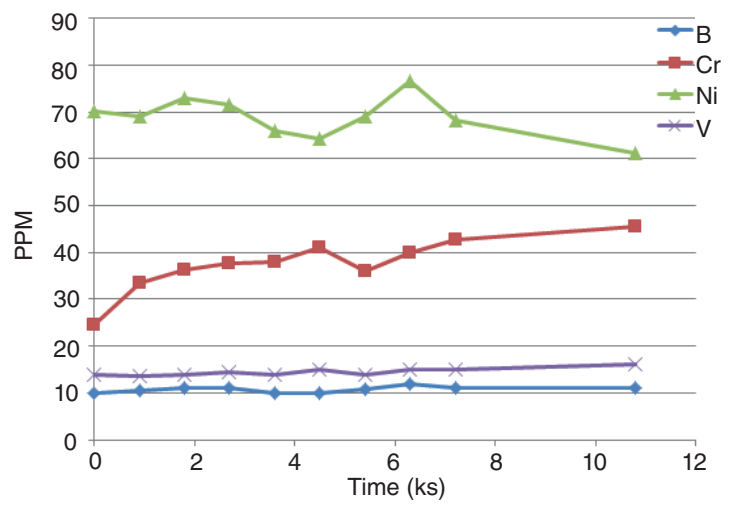

Figure 5: Time dependent variation of composition for the elements $\mathrm{B}, \mathrm{Cr}, \mathrm{Ni}$ and $\mathrm{V}$ in the bulk silicon. content of phosphorus (about $33 \mathrm{ppm}$ ) was used. The results are shown in Fig. 6 as a function of initial content of phospho$\operatorname{rus}\left(\mathrm{C}_{\mathrm{P}} / \mathrm{C}_{\mathrm{P}}{ }^{\circ}\right)$.

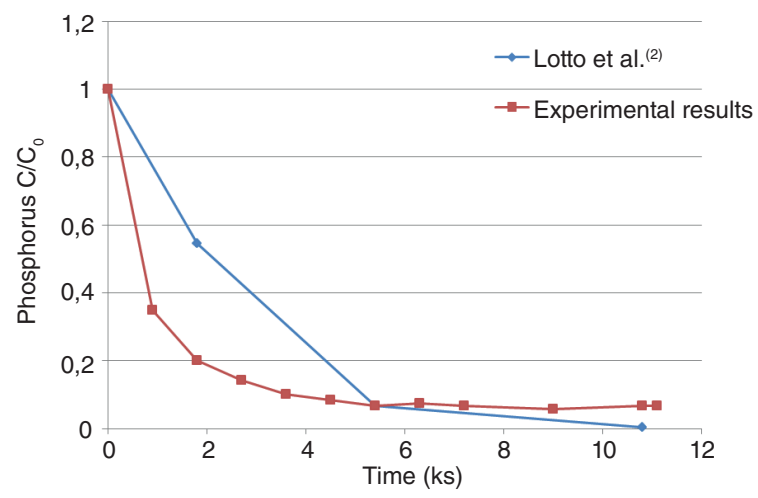

Figure 6: Comparison of phosphorus removal curve obtained in this work with another of lower initial content of phosphorus (33 ppm) presented at ${ }^{(2)}$.

The pressure used in the work of Lotto ${ }^{(2)}$ was $0.28 \mathrm{~Pa}$, against $0.2 \mathrm{~Pa}$ of this work. The temperature and crucible were the same ( $1923 \mathrm{~K}$ and crucible $\varnothing$ int $=0.098 \mathrm{~m}$ ). It may be noted that the curves are very close to each other after $5.4 \mathrm{ks})$ ( \pm 8 ppm phosphorus), but the curve obtained in the present work shows a reduction of phosphorus with time more sharply at the start of refining (from $119 \mathrm{ppm}$ to $8 \mathrm{ppm}$ ). This difference is due to the reaction be faster for higher levels of phosphorus. This phenomenon was observed by Safarian and colleagues ${ }^{(3)}$. According to them yet, the material with higher initial phosphorus content takes longer to achieve the same level of concentration to one of lower initial content.

It is possible to obtain a total mass transfer coefficient for removing impurities from silicon by the relationship shown in Eq. 1:

$$
-\frac{d_{C_{i}}}{d_{t}}=k_{i} \cdot \frac{A}{V} \cdot\left(C_{i}-C_{e i}\right)^{n}
$$

where $\mathrm{k}_{\mathrm{i}}$ is the total mass transfer coefficient of the vaporization reaction for a given element $i, C_{i}$ is the concentration of this element at time $t, C_{e i}$ is the equilibrium concentration of the $i$ element, $A$ is the surface area of evaporation, $V$ is the volume of liquid and $n$ is the order of reaction. Assuming that evaporation of i follows a first order reaction, which is the case of phosphorus monatomic, as reported in the literature, and the equilibrium concentration tends to zero, it is obtained by rearranging and integration of Eq. 2 :

$$
\ln \frac{C_{0 i}}{C_{i}}=k_{i} \cdot \frac{A}{V} \cdot t
$$

where $C_{0 i}$ is the initial concentration of the element $i$.

Figure 7 shows a curve of $\ln \left(\mathrm{C}_{0} / \mathrm{C}\right)$ as a function of $(\mathrm{A} / \mathrm{V}) t$. The angular coefficient of the straight line gives the value of the total 
mass transfer coefficient $\left(\mathrm{k}_{\mathrm{i}}\right)$ for an element $i$. At this work the coefficients obtained was: phosphorus $\left(\mathrm{k}_{\mathrm{p}}=5 \cdot 10^{-6} \mathrm{~m} / \mathrm{s}\right)$, alumi$\operatorname{num}\left(\mathrm{k}_{\mathrm{Al}}=2 \cdot 10^{-6} \mathrm{~m} / \mathrm{s}\right)$ and calcium $\left(\mathrm{k}_{\mathrm{Ca}}=1 \cdot 10^{-5} \mathrm{~m} / \mathrm{s}\right)$. Some outliers were excluded to better fit the trend line to the experimental points (larger $\mathrm{R}^{2}$ ).

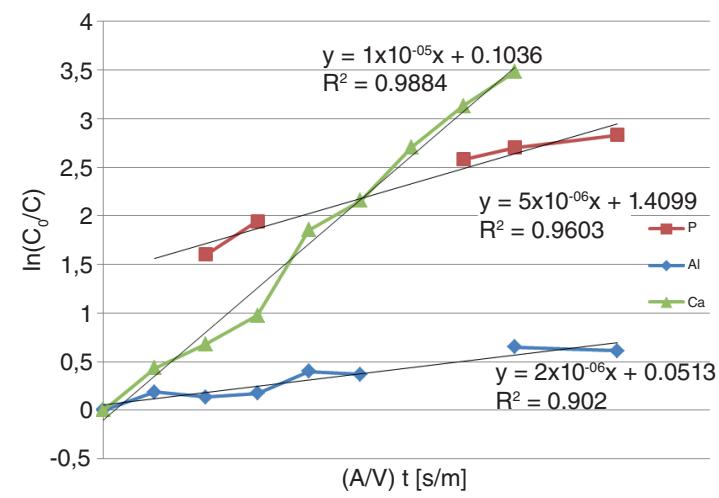

Figure 7: Variation of $\ln \left(\mathrm{C}_{0} / \mathrm{C}\right)$ versus $(\mathrm{A} / \mathrm{V}) \mathrm{t}$ to phosphorus, aluminum and calcium $\left(A / V=37.7 \mathrm{~m}^{-1}\right)$.

These values are very close to those found in the literature. Table 2 presents some values obtained in this work and other literature. An accurate comparison would be difficult due to the high differences in pressures used, but can be shown as indicative. It may be noted that in some cases values differ by an order of magnitude. This is due to the

Table 2: Data obtained in this work and literature.

\begin{tabular}{|c|c|c|c|}
\hline Autor & $k_{p}(m / s)$ & $k_{A l}(m / s)$ & $\mathrm{K}_{\mathrm{Ca}}(\mathrm{m} / \mathrm{s})$ \\
\hline This work & $\begin{array}{c}5.0 \cdot 10^{-6} \\
(1923 \mathrm{~K}) \\
(0.2 \mathrm{~Pa})\end{array}$ & $\begin{array}{c}2.0 \cdot 10^{-6} \\
(1923 \mathrm{~K}) \\
(0.2 \mathrm{~Pa})\end{array}$ & $\begin{array}{c}1 \cdot 10^{-5} \\
(1923 \mathrm{~K}) \\
(0.2 \mathrm{~Pa})\end{array}$ \\
\hline Yuge et al. ${ }^{(4)}$ & $\begin{array}{c}2.9 \cdot 10^{-5} \\
(1915 \mathrm{~K}) \\
(0.008 \mathrm{~Pa})\end{array}$ & $\begin{array}{c}1.7 \cdot 10^{-5} \\
(1915 \mathrm{~K}) \\
(0.008 \mathrm{~Pa})\end{array}$ & $\begin{array}{c}5.3 \cdot 10^{-5} \\
(1915 \mathrm{~K}) \\
(0.008 \mathrm{~Pa})\end{array}$ \\
\hline Safarian et al. ${ }^{(3)}$ & $\begin{array}{c}4.9 \cdot 10^{-6} \\
(1873 \mathrm{~K}) \\
(0.5 \mathrm{~Pa})\end{array}$ & - & - \\
\hline Lotto et al. (2) & $\begin{array}{c}7.0 \cdot 10^{-6} \\
(1923 \mathrm{~K}) \\
(0.28 \mathrm{~Pa})\end{array}$ & - & - \\
\hline Suzuki et al. ${ }^{(5)}$ & $\begin{array}{c}2.0 \cdot 10^{-5} \\
(1823 \mathrm{~K}) \\
(0.027 \mathrm{~Pa})\end{array}$ & $\begin{array}{c}1.5 \cdot 10^{-6} \\
(1823 \mathrm{~K}) \\
(0.027 \mathrm{~Pa})\end{array}$ & $\begin{array}{c}1.7 \cdot 10^{-5} \\
(1823 \mathrm{~K}) \\
(0.027 \mathrm{~Pa})\end{array}$ \\
\hline
\end{tabular}

differences in the parameters of each test and the errors inherent in the chemical analysis, especially for low concentrations.

The evaporative losses of silicon during the experiment averaged around $13 \%$, which is consistent with the model data evaporation of silicon as a function of time, temperature and pressure shown by Lotto and coworkers ${ }^{(2)}$.

\section{CONCLUSIONS}

The removal of impurities from silicon by vacuum melting is feasible for elements with higher equilibrium vapor pressure than silicon, like phosphorus. Elements with low equilibrium vapor pressure, like $\mathrm{Ti}, \mathrm{Zr}, \mathrm{Ba}, \mathrm{Co}, \mathrm{Fe}, \mathrm{B}, \mathrm{Cr}, \mathrm{Ni}$ and $\mathrm{V}$, have no changes in concentration.

The phosphorus vaporization reaction is faster in the beginning to materials with higher initial phosphorus content.

The total mass transfer coefficients obtained was: phosphorus $\left(\mathrm{k}_{\mathrm{P}}=5 \cdot 10^{-6} \mathrm{~m} / \mathrm{s}\right)$, aluminum $\left(\mathrm{k}_{\mathrm{Al}}=2 \cdot 10^{-6} \mathrm{~m} / \mathrm{s}\right)$ and calcium $\left(\mathrm{k}_{\mathrm{Ca}}=1 \cdot 10^{-5} \mathrm{~m} / \mathrm{s}\right)$ at $1923 \mathrm{~K}$ under pressure of $0.2 \mathrm{~Pa}$.

The literature data on this subject show that the experimental results obtained in this work are consistent, although parameters such as pressure and temperature are different in the major of works presented.

\section{ACKNOWLEDGEMENTS}

The authors are grateful to Companhia Ferroligas Minas Gerais (MINASLIGAS) and Banco Nacional de Desenvolvimento Econômico e Social (BNDES) for the opportunity to development of this work.

\section{REFERÊNCIAS}

1. WINKLER, O.; BAKISH, R., Vacuum Metallurgy, Elsevier, Amsterdam, 1971.

2. LOTTO, A.L.; FERREIRA NETO, J.B.; MOURÃO, M.B., Proceedings of the 68th ABM International Annual Congress (2013) 3206-3217.

3. SAFARIAN, J.; TANGSTAD, M., High Temperature Materials and Processes 31 (2012) pp.73-81.

4. YUGE, N.; HANAZAWA, K.; NISHIKAWA, K.; TERASHIMA, H.; Journal of the Japan Institute of Metals and Materials 61 (1997) pp.1086-1093.

5. SUZUKI, K.; SAKAGUCHI, K.; NAKAGIRI, T.; SANO, N.; Journal of the Japan Institute of Metals and Materials 54 (1990) pp.161-167. 